\title{
Sciendo
}

DOI 10.2478/afepuc-2021-0005

(C) 2021 Author(s). This is an open access article licensed under the Creative Commons Attribution-NonCommercial-NoDerivatives 4.0 International

(https://creativecommons.org/licenses/by-nc-nd/4.0/)

\section{THE COMPETENCE OF PROFESSORS OF PHYSICAL AND SPORTS EDUCATION IN THE USE OF MODERN TEACHING STRATEGIES FOR MIDDLE SCHOOL UNDER THE SECOND GENERATION CURRICULUM}

\author{
Bengueneb Abdarahmane, Atallah Ahmed, Djourdem Bendehiba \\ University of Abdelhamid Ibn Badis, Mostaganem, Laboratory of Programs Optimization in APS, Algeria
}

\begin{abstract}
Summary: The study aims at identifying the degree of competency of the teacher of physical education and sports in using modern teaching strategies in light of what was stipulated by the second generation. The Study sample consists of $\mathbf{6 0}$ intermediate education teachers, and relies on a list prepared by the research team consisting of two axises, each axis containing 16 items that include familiarity with and employing modern strategies in the study of physical education and sports, as well as the general organization of the lesson the data are processed statistically using the arithmetic means standard deviation, and the results showed that the teachers of Physical education and sports in middle school do not use modern teaching strategies. This is due to their lack of competence.
\end{abstract}

Keywords: Competency - the teacher of physical Education and Sports - Teaching Strategies second Generation

\section{Introduction}

The school is an educational institution which contributes to the education of the individual and helps him to grow in all aspects of his physical, psychological, mental, spiritual and social personality. It also helps to develop the will of individuals and to correctly orient their preferences and desires and modify their behavior and provide them with expertise and skills to help them adapt to the society in all areas (Bekhtaoui 2020). By expanding the process of education and improving the quality of learning at different levels of education in order to prepare children and young people in a more complex life throughout. The current century, 
which is characterized by rapid technological development, is a real measure of the development of the scientific and cultural level reached by the country. And to achieve the new and modern tasks of physical and sports education requires a departure from the traditional system of teaching based on authoritarianism at work to modern teaching, which calls for the modernization and development of curricula and their content and teaching methods to ensure that they keep up with the new developments and contemporary trends.

The process of modernization and renewal in the field of methods teaching strategies is no longer an area of discussion, but have become urgent and vital in order to balance life rapidly changing in the age of globalization and the role that educational systems should play in the interest of the student, and the learner according to these strategies, is the main focus of the educational process, where the educational curriculum is adapted from the first generation to the second generation in order to detect and enhance the potential abilities of the pupils for the results of studies such as Kaddour \& Habib (2018) and Shaheen (2006), which confirmed the importance of training and forming teachers to use various strategies in teaching, including the active learning strategy of collaborative learning, problem solving, learning by play, brainstorming, which are strategies that confirm the learner's activity in the educational process and seek to work with others in order to achieve related objectives with its comprehensive and integrated growth.

There is no doubt that the professor of physical and sports education in the middle school stage has an important role in the educational process and its main engine and is able to enhance the educational objectives and ensure the provision of educational skills to the students. Professor of Structural and Sports Education for modern teaching strategies within the class requires the availability of a range of conditions, including the selection of objectives and the organization of the content of learning, related by implementing the presentation of the lesson and the method of using educational aids and methods. This is interesting to the issue of preparing professors and studying their teaching competencies at the moment, given the importance of the role of the professor in the teaching process (Shagra 2020), where this preparation requires a special priority to show their abilities, skills and the extent to which they use the art of teaching developments and changes (Haymen 2017). It identifies the competencies necessary for the teacher of physical education to play his role to the fullest. Since change is an important, objective and orderly process, the professor has been given in his room and during his class full freedom to act using what he sees as appropriate educational methods to achieve the technical and scientific competencies required by the good functioning of the 
class. This enabled the professor to employ competencies consistent with his personality, abilities and inclinations in line with the reforms that have touched the educational system in terms of improving the educational action and adapting teachers and learners to these developments, the most prominent of which is the second generation curriculum, which was installed at the beginning of the school year 2016/2017 in compulsory education, especially in the middle school, which was based on a set of modern educational developments, as it is based on the principle of approaching competencies inspired by social structure (Haymen 2017).

In this regard, the modern trend gives the teacher the responsibility to help the student to follow the education and interest in encouraging them to take up their school work and their life matters in more creative ways, but the educational reality in the field of physical education now is completely contrary to what should be the fact that although these professional experiences are proving to be of great importance in practicing teaching work in a scientific and systematic manner, many workers in the field of education are still lacking knowledge of how to apply during the physical education lessons for proper preparation for students, especially at the level of their physical and skill abilities, this is because the understanding of the teaching process is still limited to some individual characteristics.

Several studies, including Bensikadour (2020) and Benkhaled (2015), have indicated that the use of modern active strategies in the physical and sports education contributes to the improvement and development of the educational process efficiently and effectively. And that's what matches with the conclusions of the survey and personal interview with the workers in this field of education where we noted a set of positive and negative educational practices for the teachers of physical education and sports when practicing some aspects of teaching competencies and this is what prompted us to do the current research to know and evaluate the competence of the professor of physical and sports education in the use of modern teaching strategies for the middle education under the second generation curriculum.

Based on all of the above, the questions of the problem can be raised as follows:

General question: What is the level of competence of the professor of physical and sports education in the use of modern teaching strategies for the middle school under the second generation curriculum?

Sub-questions: Does the professor of physical education and sports have the competence in the general organization of the physical and sports education lesson? IS the professor of physical and sports education competent to use the modern foundations in the teaching of physical and sports education? 


\section{Material \& methods}

\section{Participants}

2-1 The method followed in the study: The researcher used the descriptive method in a survey method due to its suitability for the nature of the current study.

2-2 Research community: The research community included teachers of physical and sports education of the middle schools in Mostaganem, where they were estimated at 189 intermediate education professors.

2-3 Sample search: Random sample among the simplest methods samples. The researcher randomly selected 60 professors of physical and sports education of middle school of Mostaganem.

2-4 Data collection tools: considered as the first stage carried out by the student to design and build up the questionnaire, and that the measured property should be based on a theoretical basis explain the educational literature has included various studies, topics, books, magazines and periodicals that are related to the subject of research and that has been used a number of sources and modern scientific references.

After drafting the questionnaire in its initial form it was presented to a group of arbitrators numbering (10) professors where the agreed journal of observations was introduced in terms of reducing in the number of axises and questions until it took its final picture.

2-5 Statistical Tools: The researcher used statistical methods like the SPSS Program in order to calculate: Percentage, Interations, Alpha - Krumbach Coefficient, Standard Deviation, the average Arithmetic, Quadratic Test( K2).

Table 1

shows the items of the questionnaire

\begin{tabular}{|l|l|l|}
\hline Number & Axes & Number of items \\
\hline 1 & $\begin{array}{l}\text { The first axis: the general organization of the physical education } \\
\text { lesson. }\end{array}$ & 16 \\
\hline $\mathbf{2}$ & $\begin{array}{l}\text { The second axis: knowledge and employment of the modern } \\
\text { foundations in the lesson of the physical education. }\end{array}$ & 16 \\
\hline
\end{tabular}

2-6 The Evaluation method and the correction key: The student researcher Mohammed (Allawi 1988) followed the method of scoring the questionnaire where the interrogator answers the items in the light of a three-step scale. (Strongly agree, agree, disagree) what corresponds to points according to each level 3-2-1 if the statement is positive and vice versa 1-2-3 if the statement is negative. 


\section{Results}

\section{3-1 Presentation and discussion of the results of the first hypothesis}

The professor of physical and sports education has the competence in the general organization of the study (lesson) of physical and sports education.

Table 2

Shows the degree of competence in the general organization of the physical and sports education lesson

\begin{tabular}{|c|c|c|c|c|c|c|}
\hline $\begin{array}{l}\text { The first axis: the general } \\
\text { organization of the study of } \\
\text { physical and sports education }\end{array}$ & $\begin{array}{l}\text { Strongly } \\
\text { agree }\end{array}$ & Agree & $\begin{array}{l}\text { I don't agree } \\
\text { (disagree) }\end{array}$ & $\begin{array}{l}\text { Estimated } \\
\text { grade }\end{array}$ & Percentage & K2 \\
\hline I often do my lessons with vigour. & 3 & 10 & 47 & 76 & 42,22 & 55,90 \\
\hline $\begin{array}{l}\text { I think the volume of the quest for } \\
\text { physical and sports education is sufficient } \\
\text { to achieve the objectives }\end{array}$ & 57 & 2 & 1 & 176 & 97,78 & 102,70 \\
\hline $\begin{array}{l}\text { I often used alternative methods to teach } \\
\text { some athletics events during the physical } \\
\text { education course }\end{array}$ & 6 & 6 & 48 & 78 & 43,33 & 58,80 \\
\hline $\begin{array}{l}\text { The institution I teach in has a valid } \\
\text { platform to teach some of the activities of } \\
\text { speed, long jump and push in }\end{array}$ & 56 & 3 & 1 & 175 & 97,22 & 97,30 \\
\hline $\begin{array}{l}\text { The institution has the athletics gear } \\
\text { necessary to teach some speed, long jump } \\
\text { and push in activities. }\end{array}$ & 48 & 8 & 4 & 164 & 91,11 & 59,20 \\
\hline $\begin{array}{l}\text { The requirements of teaching the second } \\
\text { generation curriculum in physical and } \\
\text { sports education require the teacher's } \\
\text { knowledge of strategies, methods and } \\
\text { ieaching methods }\end{array}$ & 5 & 32 & 23 & 102 & 56,67 & 18,90 \\
\hline $\begin{array}{l}\text { In preparing for physical and sports } \\
\text { education, I often rely on online } \\
\text { educational notes. }\end{array}$ & 19 & 28 & 13 & 126 & 70,00 & 5,70 \\
\hline $\begin{array}{l}\text { I make pre-planning, To study and prepare } \\
\text { for the necessary tools and procedures for } \\
\text { public safety during the lesson }\end{array}$ & 2 & 10 & 48 & 74 & 41,11 & 60,40 \\
\hline $\begin{array}{l}\text { I work on developing the student's ability } \\
\text { to investigate from the validity of the } \\
\text { skilled performance through the duty card }\end{array}$ & 5 & 20 & 35 & 90 & 50,00 & 22,50 \\
\hline $\begin{array}{l}\text { I make sure to call and organize students } \\
\text { in regiments with responsibilities. }\end{array}$ & 3 & 13 & 44 & 79 & 43,89 & 45,70 \\
\hline $\begin{array}{l}\text { I do warm-up exercises while correcting } \\
\text { performance in different situations } \\
\text { without opening the way for creative } \\
\text { practice. }\end{array}$ & 3 & 9 & 48 & 165 & 91,67 & 59,70 \\
\hline $\begin{array}{l}\text { I find it difficult to translate the goals of } \\
\text { the second generation curriculum into } \\
\text { educational modules and use an attached } \\
\text { guide in the teaching of physical and } \\
\text { sports education }\end{array}$ & 20 & 13 & 27 & 127 & 70,56 & 4,90 \\
\hline $\begin{array}{l}\text { A special configuration for the education } \\
\text { of athletics activities for students is rarely } \\
\text { programmed }\end{array}$ & 36 & 17 & 7 & 91 & 50,56 & 21,70 \\
\hline $\begin{array}{l}\text { My lessons help to take into account the } \\
\text { differences between the individuals, talent } \\
\text { discovery and ensuring participation in } \\
\text { school sports }\end{array}$ & 3 & 12 & 45 & 162 & 90,00 & 48,90 \\
\hline $\begin{array}{l}\text { My lessons help to give students basic } \\
\text { skills in handball, basketball and } \\
\text { volleyball. }\end{array}$ & 1 & 3 & 56 & 175 & 97,22 & 97,30 \\
\hline $\begin{array}{l}\text { My lessons earn students the } \\
\text { sportsmanship of accepting defeat and } \\
\text { winning and developing a spirit of } \\
\text { leadership. }\end{array}$ & 2 & 6 & 52 & 170 & 94,44 & 77,20 \\
\hline
\end{tabular}

$K 2$ table $X^{2}=5.99$ at liberty score 2 and indication level 0.05 
Through the results recorded in the table above for the first axis, the general organization of the lesson of physical education and sports, after the statistical treatment of the vertebrae and the calculation of the differences in responses using the appropriate statistical method of testing good conformity, the values of K2 were all statistically significant, with the calculated values ranging from 102.70 as the highest value to $\mathrm{K} 2$ and the lowest value of 18.90 , which is higher than the scheduled value $X^{2}=5.99$ at the degree of freedom 2 and the indication level of 0.05 . Starting from analyzing the results of the first axis items, the research team concluded that the physical and sports education lesson does not receive the great attention from the teachers of the subject in the middle school and the research team attribute this to the failure of organizing the general material of the planning and preparation of educational units that give students the spirit of initiative and leadership and take into account the differences and The lack of educational institutions in the means and equipment for athletics activities (speed-jump, throwing) on the other hand, as well as the inability to translate the objectives of the second generation curriculum of the material into educational units that would work to produce the quota properly. The results of the current study are consistent with the Madjadi (2013) study of the field of grade management and general organization of the physical and sports education quota. This is what the Study of Madani (2020) pointed out to the lack of teachers of physical and sports education in the middle and second phases to the efficiency of the management and organization of the class and the researcher attributed this deficiency to years of experience and scientific qualification

\section{3-2 - View and discuss the results of the second hypothesis}

The professor of physical and sports education is competent to use the modern foundations in the teaching of physical and sports education.

Table 3

Demonstrates the degree of competence in the use of modern foundations in the teaching of physical and sports education

\begin{tabular}{|c|c|c|c|c|c|c|}
\hline $\begin{array}{l}\text { The second axis: knowledge and employment of modern } \\
\text { foundations in the study of physical and sports education }\end{array}$ & $\begin{array}{l}\text { Strongly } \\
\text { agree }\end{array}$ & agree & $\begin{array}{l}\text { I don't agree } \\
\text { (disagree) }\end{array}$ & $\begin{array}{l}\text { Estimated } \\
\text { grade }\end{array}$ & Percentage & K2 \\
\hline $\begin{array}{l}\text { I had a special composition for modern strategies in physical } \\
\text { education and sports }\end{array}$ & 48 & 7 & 5 & 163 & 90,56 & 58,90 \\
\hline $\begin{array}{l}\text { I had a special training in the field of roads and teaching } \\
\text { methods. }\end{array}$ & 46 & 10 & 4 & 162 & 90,00 & 51,60 \\
\hline $\begin{array}{l}\text { I often involve my students in completing the lesson } \\
\text { according to the goals set. }\end{array}$ & 6 & 47 & 7 & 119 & 66,11 & 54,70 \\
\hline $\begin{array}{l}\text { I often use collaborative learning to teach various physical } \\
\text { and sports activities. }\end{array}$ & 7 & 44 & 9 & 118 & 65,56 & 43,30 \\
\hline $\begin{array}{l}\text { I have a knowledge of modern teaching methods in physical } \\
\text { and sports education. }\end{array}$ & 8 & 40 & 12 & 116 & 64,44 & 30,40 \\
\hline I count and rely on teaching experience. & 3 & 12 & 45 & 78 & 43,33 & 48,90 \\
\hline $\begin{array}{l}\text { I often design an assignment card explaining the performance } \\
\text { and feedback criteria according to the purpose and objective } \\
\text { of the lesson. }\end{array}$ & 31 & 25 & 4 & 147 & 81,67 & 20,10 \\
\hline $\begin{array}{l}\text { I often pave the way to practices according to the students' } \\
\text { inclinations without prior preparation. }\end{array}$ & 35 & 20 & 5 & 150 & 83,33 & 22,50 \\
\hline
\end{tabular}




\begin{tabular}{|c|c|c|c|c|c|c|}
\hline $\begin{array}{l}\text { I find it difficult to improve and develop the physical and skill } \\
\text { performance of students during the physical and sports } \\
\text { education course }\end{array}$ & 15 & 26 & 19 & 116 & 64,44 & 3,10 \\
\hline $\begin{array}{l}\text { I always design educational positions in the form of problems } \\
\text { and solutions are left to the student }\end{array}$ & 25 & 23 & 12 & 133 & 73,89 & 4,90 \\
\hline $\begin{array}{l}\text { My students had the opportunity to discover the right } \\
\text { performance with questions from me to get the right answer. }\end{array}$ & 31 & 25 & 4 & 147 & 81,67 & 20,10 \\
\hline $\begin{array}{l}\text { I often rely on collaborative learning in the design of learning } \\
\text { attitudes }\end{array}$ & 7 & 44 & 9 & 118 & 65,56 & 43,30 \\
\hline $\begin{array}{l}\text { I often rely on the meeting of pedagogical team in the } \\
\text { development of my teaching skills according to the outputs } \\
\text { of the second generation curriculum }\end{array}$ & 26 & 13 & 21 & 125 & 69,44 & 4,30 \\
\hline $\begin{array}{l}\text { I rarely work on diversity in the recruitment of teaching } \\
\text { strategies. }\end{array}$ & 8 & 14 & 38 & 150 & 83,33 & 25,20 \\
\hline $\begin{array}{l}\text { I'm usually responsible for all the lesson decisions on my } \\
\text { own, and the role of the students lies only in work. }\end{array}$ & 2 & 17 & 41 & 81 & 45,00 & 38,70 \\
\hline $\begin{array}{l}\text { I often rely on my own way of controlling and taking out the } \\
\text { lesson. }\end{array}$ & 8 & 20 & 32 & 96 & 53,33 & 14,40 \\
\hline
\end{tabular}

$K 2$ table $X^{2}=5.99$ at D.H2 and the indication level 0.05

Through the results recorded in the table above for the second axis, the knowledge and employment of the modern foundations in the study of physical and sports education and after the statistical treatment of items and by calculating the differences in responses using the appropriate statistical method of testing good conformity, the values of K2 were all statistically significant, with the calculated values ranging from $58.90 \mathrm{k}$ the highest value to $\mathrm{K} 2$ and the lowest value of 14.4 is greater than the scheduled value $\mathrm{X}^{2}=5.99$ at the degree of liberty 2 and the indication level of 0.05 .

Based on the analysis of the results of the second axis paragraphs, the research team concluded that there is a great lack of competencies of teachers of physical and sports education in the middle school in terms of knowledge and theory of modern teaching strategies, especially based on cooperative learning and solving problems focused on the learner and relying on the old approach i.e. traditional teaching based on privacy, which directly affects the class, and the level of the student and the extent of its integration into the class. The results of the study that the teachers of physical education in the secondary level are not familiar with the teaching competence, including the competence of the use and employment of teaching strategies in the study of physical and sports education, and the results of the current study differed with the study of Kaddour \& Habib (2018), which resulted that the teachers of physical and sports education are competent in the use of modern teaching strategies of self-learning, collaborative learning and learning by play. Madani (2020) also attributed this to the years of experience and scientific qualification variable, which in turn affects the degree of practicing the efficiency of employing and using modern strategies in teaching physical education and sports. 


\section{Discussions}

- There is a discrepancy in the use of teaching strategies by teachers of physical and sports education in the middle school.

- No differences in the degree of the practice and the use of the teachers of physical and sports education for teaching strategies under the second generation curriculum.

- Teaching physical and sports education in the middle school is limited to authoritarianism and that the teacher is the focus of the educational process and the role of the learner remains negative.

\section{Conclusion}

As the reforms that covered all fields, it was necessary to revolutionize the educational system and rebuild strong educational systems that raise the level of the aspirations of the learner and to appreciate these reforms and changes had to be carried out by researchers of the educational sector to carry out a comprehensive evaluation of the educational system in the form of the educational process in a special form in light of the developments and challenges of the present. And based on the premise, the development of the material stems from the development of the teaching process by re-modifying the educational curriculum in line with the modern active strategies. The researcher's team concluded that despite the fact that teachers of physical education and sports in the middle school are aware of modern strategies by $85 \%$, and their application within lessons are almost non-existent and it is clear that $79 \%$ do not use it despite their knowledge and this is what the problem of the research at hand appreciates.

Finally, we hope that we have contributed to this modest work in a positive way to present and address the aspects of the study, and there is no doubt that things were worth it. We have interpreted and deepened, but we have not met their right, and we hope that we have given new horizons for research and studies in this subject despite all the difficulties and challenges.

\section{References}

1. HAYMEN, A., 2017. Evaluation of the teaching qualifications of the teacher of sports education in the basic stage of the first edition.Alexandria. Alxendaria: Al Waffa Donia Printing House.

2. AL-HAYEK, S. K., 2018. Contemporary Methods and Strategies In Teaching Physical Education Jordan Hashemite Kingdom Of Jordan. Jordan. 
3. ASUN, S. \& M. CHIVITE, 2020. Perception Of Professional Competences in Physical Education Teacher Education (PETE). Sustainability. 12(12), 12-38. https://www.mdpi.com/2071-1050/12/9/3812/htm

4. DAVIS, R., 2000. Teacher Evalution. USA: Introduction.

5. BKHTAOUI, D. \& D. MOKRANI, 2020. Analysis OF educational Process In Teaching Physical And Sports Activites Collectives Competency Approach. Physical Education and Sport Through The Centuries. 7 (2), 189-198.

https://content.sciendo.com/view/journals/spes/7/2/articlep189.xml?rskey=AnRkFa\&result $=1$

6. BENKHALED, H., 2015. Using some educational strategies to embody the applicationApproach ing competencies in the physical and sports education lesson. Mostaganem.

7. IBRAHIM, N. \& M. KHAFAHA, 2002. Teaching in physical education. Alexandaria, Egypte: Radiation Libarary and Printing Press.

8. BRAHIMI, K. et al., 2018. The Effectiveness of using the selfL learning Strategy to Learn the Skill of sending Tennis to Students(16-18) years in Volleyball. Journal of Sports System. 5(1), 208-222. https://www.asjp.cerist.dz/en/article/50324.

9. MADANI, B., 2020. A calendar analytical study of the objectives of educational units based on pedagogical competences for teachers of physical and sports education. Journal of Sports System. 6(2), 234-254. https://www.asjp.cerist.dz/en/article/100065.

10. BENSIKADOUR, H. et al., 2020. The effectiveness of the active learning strategy in the workshops in the practice of athletics activities children to improve the elements of physical performance and digital achievement in the running sequence (4-60). Sports Creativity. 11 (1), 437-454. https://www.asjp.cerist.dz/en/article/116200.

11. MAHER, M. R. et al., 2013. Initial training and appropriation of professional skills by trainee teachers in physical education and sports (EPS). IOSR Journal OfRresearch Method In Education (IOSR-JRME). 1 (6), 1-12. https://www.researchgate.net/publication/315317468

12. CARLSON, S. A., J. E. FULTON \& S. M. LEE, 2008. Physical Education and Academic Arshivement In Elementary School. Amarican Journal Of Public Health. 721-727.

13. SALAH, H., 2018. Modern Teaching Strategies. Amman, Jordan: Dar Al-Massira For Pubilshing. 
14. SHAGRA, Y. B., 2020. The level of qualification of the teachers of physical and sports education and its relation to certain variables.

15. TALEB, A., 2015. The competence of the Professor of Physical and Sports Education and its impact on the educational scientific quality in secondary school.Sports Creativity. Scientific Journal Of Science and Technology For Physical and Sports Activities. 12(12), 208-229. https://www.asjp.cerist.dz/en/article/127. 